Niniejsza publikacja jest dostępna na licencji Creative Commons. Uznanie autorstwa-Użycie niekomercyjne-Bez utworów zależnych 3.0 Polska. Pewne prawa zastrzeżone na rzecz autora. Zezwala się na wykorzystanie publikacji zgodnie z licencja - pod warunkiem zachowania niniejszej informacji licencyjnej oraz wskazania autora jako właściciela praw do tekstu. Treść licencji jest dostępna na stronie: http://creativecommons.org/licenses/by-nc-nd/3.0/pl/

Lingwistyka Stosowana 23: 3/2018, 167-179

\author{
Marcin LĄCZEK \\ Uniwersytet Warszawski
}

\title{
Funkcja facylitacyjna angielskiej polityki oświatowej w zakresie kształcenia mniejszości etnicznych (przypadek inspektoratu oświaty w Milton Keynes)
}

\begin{abstract}
:
The facilitative function of English educational policy with regard to ethnic minorities (based on Milton Keynes LEA)

The article concentrates on the facilitative function of English educational policy with regard to education of ethnic minorities. At its beginning the author focuses on the major assumptions of Education and Inspections Act 2006; a reference is made to European educational policy regarding newly arrived minority students (NAMS), too. In the further course of his analyses he refers to different means of support of ethnic minority pupils included in Guidance on the assessment of EAL pupils who may have special educational needs prepared by Ethnic Minority Achievement Support Service (EMASS) employees from Milton Keynes local education authority.
\end{abstract}

\section{Wstęp}

Autor niniejszej publikacji, po nakreśleniu głównych założeń angielskiej (oraz europejskiej) polityki oświatowej w odniesieniu do uczniów przynależących do różnych mniejszości etnicznych, przywoła różne sposoby ich wsparcia opracowane przez pracowników departamentu ds. mniejszości etnicznych (Ethnic Minority Achievement Support Service, EMASS) działającego przy inspektoracie oświaty w Milton Keynes ${ }^{1}$ w porozumieniu ze szkołami usytuowanymi na terenie tegoż miasta, sekcją ds. wsparcia szkolnictwa specjalnego oraz innymi inspektoratami oświaty.

\footnotetext{
${ }^{1}$ Mniejszości etniczne stanowią 14,5\% populacji szkolnej w Milton Keynes, z czego 8,5 \% to uczniowie posługujący się angielskim jako językiem dodatkowym (English as an additional language, EAL) (Guidance on the assessment of EAL pupils who may have special educational needs 2004). Z kolei zgodnie z danymi uzyskanymi podczas Spisu Ludności z 2011 roku dla Anglii i Walii (England and Wales Census) Ealing jest obszarem najgęściej zaludnionym przez osoby urodzone w Polsce ze wskaźnikiem 13,18\% (London: Census Profile 2015. Zob. także: M. Łączek 2014, 2015a, 2015b. W skali europejskiej migracja netto potroiła się od roku 1960 (The study on educational support to newly arrived migrant children 2013 za: Migrants in Europe. A Statistical portrait of the first and second generation 2011).
} 
Artykuł nie ma na celu dokonania wszechstronnego i wyczerpującego opisu przedmiotowego zagadnienia, a jedynie jego zasygnalizowanie. Co więcej, ewentualne odstępstwa w niektórych kwestiach poruszonych w niniejszej publikacji mogą być następstwem autorskiej polityki szkoły w danym aspekcie w jednym, kilku bądź wszystkich pięciu tzw. okresach kluczowych (key stages, KS): KS1 (5-7 lat), KS2 (7-11 lat), KS3 (11-14 lat), KS4 (14-16 lat) i KS5 (16-19 lat)2 .

\section{Główne założenia Education and Inspections Act (a założenia polityki euro- pejskiej)}

System oświaty w Anglii i Walii regulowany jest poprzez The Education and Inspections Act z 8 listopada 2006 roku (Education and Inspections Act 2006: 1); przywołana ustawa zastąpiła wówczas obowiązującą The Education Act z 2002 roku' $^{3}$ :
[a]n Act to make provision about primary, secondary and further education and about training; to make provision about food or drink provided on school premises or in con- nection with the provision of education or childcare; to provide for the establishment of an Office for Standards in Education, Children's Services and Skills and the appointment of Her Majesty's Chief Inspector of Education, Children's Services and Skills and make provision about the functions of that Office and that Chief Inspector; to provide for the amendment of references to local education authorities and children's services authori- ties; to amend section 29 of the Leasehold Reform Act 1967 in relation to university bod- ies; and for connected purposes.

Obecna wersja Ustawy składa się z dziesięciu części: 1.Education functions of local authorities, 2. Establishment, discontinuance of alteration of schools, 3. Further provisions about maintained schools, 4. Schools causing concern: England, 5. Curriculum and entitlements, 6. School travel and school food, 7. Discipline, behaviour and exclusion, 8. Inspections, 9. Miscellaneous, 10. General oraz osiemnastu załączników: 1. Amendments related to section 6, 2. Proposals for establishment or discontinuance of schools in England, 3. Amendments relating to school organisation, 4. Disposals and changes of use of land, 5. Funding of maintained schools, 6. Governing bodies consisting of interim executive members, 7. Amendments relating to schools causing concern, 8. Travel to schools etc.: meaning of "eligible child", 9. School travel schemes, 10. Further amendments relating to travel to schools etc., 11. The Office for Standards in Education, Children's Services and Skills, 12. The Chief Inspector and other inspectors etc., 13. Interaction with other authorities, 14. Minor and consequential amendments relating to part 8, 15. Transitional provisions and

\footnotetext{
${ }^{2}$ Więcej informacji o angielskim systemie oświaty zob.: M. Łączek 2006.

${ }^{3}$ Ten sam system oświaty w państwach przynależących do Zjednoczonego Królestwa Wielkiej Brytanii i Irlandii Północnej obowiązuje jedynie w Anglii i Walii, co było następstwem wprowadzenia w 1998 roku tego samego programu nauczania (dla szkół podstawowych i średnich): National Curriculum. Przedmiotem zainteresowania autora w przedmiotowej publikacji będzie wyłącznie obszar Anglii - różnice pomiędzy Anglią, Wielką Brytanią, Zjednoczonym Królestwem Wielkiej Brytanii i Irlandii Północnej a Wyspami Brytyjskimi wyjaśnia np. J. O’Driscoll 1995.
} 
savings relating to part 8,16 . Powers to facilitate innovation, 17. Miscellaneous amendments relating to Wales, 18 . Repeals.

W Ustawie brak jest jakiejkolwiek wzmianki o kształceniu uczniów przynależących do mniejszości etnicznych sensu stricto. Sensu largo, pojawia się natomiast zapis o obowiązku promowania spójności społecznej (community cohesion) w części 3: Further provisions about maintained schools $\mathrm{w}$ art. $33 \mathrm{w}$ ust. 1,6 $\mathrm{i} \mathrm{w}$ art. $38 \mathrm{w}$ ustępie 1,5 (b) oraz w części 8: Inspections w rozdziale 7 Miscellaneous and supplementary $\mathrm{w}$ art. 154 Duty to report on contribution of certain schools to community cohesion. Obowiązek ten, nałożony na ciała zarządzające szkołami publicznymi, nastał z dniem 1 września 2007 roku$^{4}$. Poza tym, w części 9: Miscellaneous rzeczonej Ustawy art. 173 i 174 są poświęcone, odpowiednio: Special educational needs co-ordinators oraz Time limits relating to statements of special educational needs. Konieczność rozwijania spójności społecznej (social cohesion) podkreślono kilka lat wcześniej w raporcie Komisji Europejskiej The concrete future objectives of education systems z 2001 roku: "[t]hey [member states] also stress the role which the education systems must play in developing social cohesion, and in attracting people with difficulties or from minorities into learning so that they can be enabled to play their full part in society" (2001: 4).

W kontekście przywołanej powyżej polityki europejskiej ${ }^{5}$ na szczególną uwagę zasługuje raport Study on educational support for newly arrived migrant children. Final report (2013), którego cel jest dwojaki: 1. przeanalizować politykę i udzielić wskazówek w zakresie wsparcia nowo przybyłych dzieci migrantów (newly arrived migrant students, NAMS) w procesie kształcenia, 2. przedstawić przykłady dobrych praktyk stosowanych przy wsparciu nowo przybyłych dzieci migrantów w procesie kształcenia; jak zaznaczają Autorzy - zwłaszcza tych praktyk, które zostały poddane ocenie i są zatem możliwe do dalszego propagowania. Raport (2013) składa się z sześciu rozdziałów: 1. Research context (wyróżnione podrozdziały to: Newly arrived migrants as a distinctive category in education studies, Factors affecting the integration of NAMS into formal education, Educational support for newly arrived migrant children), 2. Methodology (Framework for analysis, Scope of the study, Research design), 3. Educational support for newly arrived migrant students in europe (sic!): comparative analysis (Targeting of NAMS in education, Education system design characteristics), 4. Educational support models, 5. Performance of educational support models (Reaching objectives of better NAMS inclusion, Other factors explaining country differences in integration of NAMS), 6. Towards an effective comprehensive

\footnotetext{
${ }^{4}$ Szkoły są prawnie zobligowane do aktywnego promowania równości rasowej (racial equality) zgodnie z Race Relations (Amendment) Act z 2000 roku. W odpowiedzi na Raport R. MacPhersona wprowadzono w 2002 roku we wszystkich szkołach państwowych na terenie Anglii i Walii przedmiot o nazwie Citizenship Education (CE).

${ }^{5}$ Od początku lat siedemdziesiątych w kontekście prac nad migracją w Europie Zachodniej (a w odniesieniu do języków mniejszościowych) Rada przyjęła dwie Konwencje i kilka Rekomendacji - zob. np. The Framework Convention for the Protection of National Minorities, The European Charter for Regional or Minority Languages, Recommendation No. R (98)6 of the Committee of Ministers; w ostatniej dekadzie uległy one zresztą rozszerzeniu o mniejszości narodowe.
} 
and inclusive model (Framework conditions - education system characteristics, Thematic support policies ${ }^{6}$, Monitoring and policy implementation). Autorzy The study on educational support for newly arrived migrant children (2013) opracowali trzy główne zalecenia, które decydenci powinni wziąć pod uwagę przy projektowaniu polityki integracyjnej dla nowo przybyłych dzieci migrantów poprzez edukację: 1 . zintegrowane podejście w procesie inkluzji, 2. identyfikacja nowo przybyłych dzieci migrantów jako konkretnej grupy docelowej w edukacji nie jest warunkiem koniecznym do posiadania dobrej i kompleksowej polityki integracyjnej, 3. celem skutecznej realizacji wdrażanych polityk, na szczeblu krajowym, powinny być zapewnione dyskrecja i nadzór. Obecnie, niestety, istnieją rozbieżności w realizacji krajowych priorytetów na poziomie regionalnym i lokalnym, mimo że większość krajów europejskich uznaje znaczenie integracji nowo przybyłych dzieci migrantów w systemie edukacji na poziomie europejskiej polityki (niektóre kraje mają długą historię imigracji, podczas gdy inne doświadczyły bezprecedensowego wzrostu w tym zakresie w ostatniej dekadzie) ${ }^{7}$. W konsekwencji, w raporcie (The study on educational support to newly arrived migrant children 2013: 7-8) wyróżniono następującą typologię systemów wsparcia edukacyjnego nowo przybyłych dzieci migrantów:

\section{$>$ comprehensive support model (np. Dania, Szwecja) -}

[c]omprehensiveness of the support implies that all four types of support are well developed and education systems are in other ways inclusive. Countries representing this model provide continuous support to development of linguistic skills, teaching support and assistance in transferring students to higher levels of education. Decentralised education and high school autonomy goes together with strong focus on outreach to parents and local community. Intercultural learning is mainstreamed into education. Countries pay a lot of attention to creating a positive school environment through trained teaching staff and various intercultural initiatives;

\section{$>$ non-systematic support model (np. Włochy, Cypr, Grecja) -}

[t]he model is characterised by randomness of the support provided. Countries that are attributed to this group have no clearly articulated policy on the national level to support the integration of newly arrived migrant children or such policy exists, but is not effectively resourced and implemented. The support provided at regional, local and/or school level is highly fragmented as teachers, parents and local communities are largely left to their own devices;

\section{compensatory support model (np. Belgia, Austria) -}

[ $t$ ] he model includes all types of support policies with only academic support being a rather weak aspect that is further undermined by early ability tracking and streaming systems. Countries provide ongoing teaching of the host language as a second language and

\footnotetext{
${ }^{6}$ Poddane analizie bloki tematyczne to: Linguistic support, Academic support, Parental and community involvement, Intercultural education.

${ }^{7}$ W roku akademickim 2009/2010 zarejestrowany w szkołach austriackich odsetek uczniów z pierwszym językiem innym niż niemiecki wynosił 17,6\% (The study on educational support to newly arrived migrant children 2013).
} 
the mother tongue to the largest groups of migrants (e.g. Austria in regular schools). Parents of NAMS are encouraged to cooperate with schools through the provision of resource persons and interpretation services. The support provided is essentially compensatory aiming to correct the 'differences' between immigrant and native students, rather than tackling the initial disadvantage;

\section{$>$ integration model (np. Irlandia) -}

[1]inguistic support is not a central focus of this model as it stops after several introductory years and no mother tongue teaching or teaching English as a second language is offered continuously throughout the schooling process. The systems for welcoming NAMS, arrangements for assessment of prior schooling and support programs for underachieving students are well developed. Particular strengths of this model are well developed outreach and cooperation and intercultural education policies. Liaison between school, parents and local community is systematic, while intercultural learning is well integrated into the curricula and promoted in school daily life;

\section{$>$ centralised entry support model (np. Francja, Luksemburg) -}

[t] he focus of the model is on the centralised reception of migrant children and the provision of academic support as the main driver of educational inclusion. Both countries provide a centralised reception desk, assessment of prior schooling and welcoming arrangements for NAMS. Targeted support programmes for underachieving students are well developed. Linguistic support and outreach to migrant parents/communities are also rather well developed.

Godnym polecenia jest także raport A. F. Atger (2009) Education and political participation of migrants and ethnic minorities in the EU, celem którego jest przedstawienie ogólnego zarysu dotyczącego ewoluowania sposobów połączenia udziału migrantów i mniejszości etnicznych w edukacji i polityce przy wsparciu polityki Unii Europejskiej. Pierwszym prawnie wiążącym instrumentem, w którym pojawiło się tego rodzaju połączenie była dyrektywa z 1977 roku: Council Directive 77/486/EEC on the education of children of migrant workers, choć, jak zauważa Autorka (2009), według Komisji Europejskiej jej implementacja, 30 lat później, nadal nie jest satysfakcjonująca ${ }^{8}$.

Dla szerszego porównania, na gruncie polskim chciałbym przywołać dwa dokumenty: przygotowaną przez zespół ekspertów i wydaną w 2010 roku przez Ministerstwo Edukacji Narodowej Podstawe programowa dla uczniów polskich uczacych się za granica oraz zrealizowany przy wsparciu Komisji Europejskiej program badawczy Socrates - Akcje 6.1.2 i 6.2 „Wielojęzyczność a wykorzystanie różnorodności kontekstów europejskich w nauczaniu szkolnym. Wyniki badań w dzielnicy Grunwald w Poznaniu oraz w powiecie słubickim na tle innych okręgów europejskich" z 2007 roku. Koordynatorem przywołanego powyżej projektu był Université de Liège (Belgia) Unité d'analyse des systèmes et des pratiques d'enseignement, a partnerami:

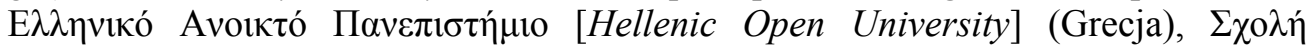

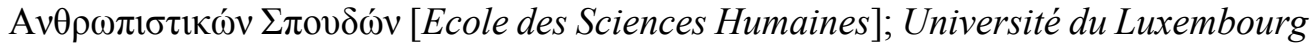

${ }^{8}$ Równie ciekawe i przydatne informacje dostępne są na stronie European Union Agency for Fundamental Rights: http://fra.europa.eu/en/tags/minorities. 
(Luksemburg), Educational Measurement and Applied Cognitive Science; Justus-Liebig-Universität Gießen (Niemcy), Abt. Didaktik der romanischen Sprachen oraz Uniwersytet im. A. Mickiewicza (Polska), Instytut Filologii Romańskiej. Część 3 przedmiotowego dokumentu: „Ogólny opis polskiego kontekstu badania”, a ściślej rozdział 3 „Charakterystyka ekonomiczno-demograficzna”, zawiera podrozdział (3.3) „Mniejszości narodowe i etniczne w Polsce" poświęcony kształceniu dzieci i młodzieży należącej do mniejszości narodowej lub grupy etnicznej. Na uwagę zasługują również monografie E. Lipińskiej (2013) i R. Laskowskiego (2009, 2014); pierwsza zajmuje się problematyką dwujęzyczności, edukacji i problemach adaptacyjnych Polonii w Australii, druga - przyswajaniem języka polskiego w warunkach polsko-szwedzkiego bilingwizmu.

Nie będzie zbyt odkrywczą konstatacją, że ustawa jest aktem prawnym powszechnie obowiązującym na terenie danego kraju; równie istotne z punktu widzenia niniejszej analizy będą także założenia lokalnej polityki oświatowej realizowane poprzez odpowiednią dokumentację, w tym wewnątrzszkolną. Dalsza część bieżącego opracowania poświęcona będzie dokumentowi Guidance on the assessment of EAL pupils who may have special educational needs (2004) opracowanemu przez inspektorat oświaty w Milton Keynes choć warto w tym miejscu odnotować istnienie jeszcze jednego dokumentu o nazwie The national literacy strategy (1999 z późn. zm.), a zwłaszcza (kompatybilnych i wzajemnie się uzupełniających) sekcji takich jak np.: Supporting pupils learning English as an additional language czy Learning and teaching for bilingual children, zgodnych z Children Act (1989).

\section{Mniejszości etniczne w optyce lokalnej angielskiej polityki oświatowej (przypadek inspektoratu oświaty w Milton Keynes)}

Dzieci i młodzież będące członkami mniejszości etnicznych do czasu ukończenia angielskich szkól ${ }^{9}$ pozostają pod opieką szkolnych jednostek organizacyjnych o nazwie Special Educational Needs Departments lub English as an Additional Language Departments (w zależności od wewnętrznej struktury danej szkoły te drugie często podlegają koordynatorom tych pierwszych). Zastrzec w tym miejscu należy, że uczniowie (bynajmniej w teorii - praktyka, jak doświadczył autor niniejszej publikacji, jest nieco inna), których problemy w nauce pojawiają się na skutek odmiennego kraju pochodzenia (tj. angielski nie jest dla nich językiem ojczystym) nie powinni być postrzegani jako uczniowie posiadający specjalne potrzeby edukacyjne, chyba, że doświadczają jednocześnie innych trudności takich jak np. dysleksja, dysgrafia, dysortografia, deficyt funkcji słuchowych, deficyt funkcji wzrokowych czy zaburzeń o podłożu emocjonalnym. Guidance on the assessment of EAL pupils who may have special educational needs $(2004)^{10}$ podzielony jest na 12 części:

\footnotetext{
${ }^{9}$ Obowiązkowy wiek szkolny to 16 lat.

${ }^{10}$ Rzeczony dokument (2004) obowiązywał w przeważającej większości szkół (także z innych hrabstw), w których pracował autor niniejszego artykułu. Dużą popularnością cieszyły się również opracowania firmy Hounslow Language Service Ltd usytuowanej w jednej z 32 gmin Wielkiego Londynu (http://www.ealhls.org.uk/).
} 
1. Introduction, gdzie m. in. podkreśla się za dokumentem Special Educational Needs Code of Practice (2001), iż termin „,specjalne potrzeby edukacyjne” oznacza w tym kontekście wyłącznie „specjalne potrzeby językowe” uczniów posługujących się angielskim jako językiem dodatkowym bowiem "[a] pupil is not to be taken as having a learning difficulty solely because the language (or form of language) in which he is, or will be, taught is different from a language (or form of language) which has at any time been spoken in his home" (2004: 4) ${ }^{11}$. Poza tym, jak podkreślają autorzy Guidance on the assessment of pupils with English as an additional language who may have special educational needs (2004), przedmiotowy dokument koncentruje się na potrzebach kognitywnych uczniów posługujących się angielskim jako językiem dodatkowym aniżeli fizycznych czy sensorycznych;

2. Histories of bilingualism and their impact on educational achievement, w której, m. in., Autorzy w oparciu o prace T. Skuttnab-Kangas (1984) i T. Cline'a (2001) przywołują, wraz z jej charakterystyką, typologię dwujęzyczności uwzględniając podział na dwujęzyczność: a. elitarną (elite bilingualism), b. większościową (majority bilingualism), c. rodzinną (family bilingualism) i d. mniejszościową (minority bilingualism) ${ }^{12}$;

3. Challenges faced by minority bilingual pupils in schools ${ }^{13}$, gdzie m. in. podkreśla się, iż w ciągu dwóch lat uczniowie rozwijają podstawowy język ,przetrwania", dzięki któremu będą w stanie funkcjonować na placu zabaw czy środowisku społecznym, a nabycie pełnych umiejętności czytania i pisania (tak, aby sprawnie operować w treściach programu nauczania) zajmuje od lat pięciu do siedmiu;

4. Social and educational needs of EAL learners, w której Autorzy m. in. podają przykłady strategii, z których korzystają uczniowie uczący się angielskiego jako języka dodatkowego ${ }^{14}$;

5. The legal position, gdzie m. in. przywołuje się dokument o nazwie The SEN Code of Practice (2001), a w szczególności fragment mówiący, iż “[1]ack of competence in English should not be equated with learning difficulties, but when pupils who have EAL make slow progress it should not be assumed that

\footnotetext{
${ }^{11}$ Niezwykle interesujące są wyniki trwającego pięć lat badania przeprowadzonego przez Institute for Fiscal Studies (IFS), według którego reprezentanci mniejszości etnicznych z dużo większym prawdopodobieństwem kontynuują naukę na poziomie uniwersyteckim, niż ma to miejsce w przypadku białych Brytyjczyków wywodzących się z klasy średniej (Ethnic minorities 'more likely to go to university' than white working-class British children 2015).

${ }^{12} \mathrm{~W}$ swoich rozważaniach podążam za definicjami takich uczonych jak, m. in.:. T. K. Bhatia/ W. C. Ritchie 2004, E. Bialystok 2001, L. Bloomfield 1933, S. Döpke 1992, F. Grosjean 1982, F. Grucza 1981, S. Grucza 2013, I. Kurcz 2007, A. Lam 2006, E. Lipińska 2013, E. Lipińska/ A. Seretny 2012, E. Peal/ W. E. Lambert 2007 czy M. Olpińska-Szkiełko 2013a, 2013b. Zob.: M. Łączek 2016a - nie będę ich tutaj streszczać ponownie.

${ }^{13} \mathrm{~W}$ spisie treści nazwa tej części to: Challenges faced by minority ethnic pupils in schools. ${ }^{14}$ Zob. także: M. Łączek 2014.
} 
their language status is the only reason they may be having learning difficulties";

6. Identification and assessment, w której Autorzy m. in. wyszczególniają główne wyzwania, które stoją przed uczniami uczącymi się angielskiego jako języka dodatkowego, tj.: a. słownictwo, b. wiedza syntaktyczna, c. odnośniki o charakterze kulturowym, d. inferencja i e. idiomy.

Ta część zawiera też w sobie sekcje poświęcone następującym zagadnieniom: a. Triggers for cause for concern, b. Language or learning need, c. Collection of background information, d. Language Acquisition Level (inspektorat oświaty w Milton Keynes LEA zaadaptował system oceny akwizycji języka angielskiego o nazwie Northern Association of Support Services for Equality and Achievement (NASSEA), w wyniku którego uczniowie są oceniani pod kątem następujących czterech umiejętności: słuchanie i rozumienie, mówienie, czytanie i pisanie, e. First language assessment, f. Teaching strategies employed in school, g. Formative and summative assessment, h. Standardised assessments;

7. Cause for concern, gdzie rozgranicza się pomiędzy podłożem sytuacji stwarzających powody do obaw;

8. Individual Education Plans podzielony na sekcje o tematyce: a. A co-ordinated response to SEN provision i b. Guidance for supporting EAL pupils on the SEN register ${ }^{15}$;

9. Ways forward;

10. Appendices składającej się z 9 załączników: 1. Background information. Addendum to the school admission form for minority ethnic pupils; załącznik zawiera następujące sekcje: a. Family information, b. Pupil's use of language, c. Previous schooling, d. support for learning, e. Dietary and health issues, $\mathrm{f}$. Support for patents and carers, 2. Class teacher consultation of language or learning need, 3. Pupil consultation of language or learning need, 4. Needs observation, 5. Parent consultation of language or learning need, 6. NASSEA EAL assessment system - każda z czterech umiejętności (słuchanie i rozumienie, mówienie, czytanie oraz pisanie) oceniana jest według siedmiostopniowej skali: step 1 (S1), step 2 (S2), threshold (S3), secure (S4), consolidating (S5), competent (S6), independent (S7), 7. A comparison between NASSEA steps and National Curriculum levels - zestawienie zawiera porównanie w odnisieniu do czterech okresów kluczowych, tj. KS1, KS2, KS3 i KS4 (a więc poziom szkoły podstawowej i średniej), 8. Example of first language assessment (key stage 1), w którym wyróżniono takie sekcje jak: a. narrative, b. sequencing, c. relating personal experience, d. comprehension, e. following verbal instructions, f. memory, g. comments by the assessor, 9. Strategies for supporting pupils with English as an additional language;

11. Sources of information;

12. Acknowledgements.

${ }^{15} \mathrm{~W}$ spisie treści nazwa tej części to: Guidance for supporting bilingual pupils on the SEN register. 
Wymieniony w punkcie 8 ,Indywidualny Plan Kształcenia” jest ostatnim podejmowanym krokiem $\mathrm{w}$ procesie ustalania trudności w uczeniu się/ nauczaniu ucznia przynależącego do danej mniejszości etnicznej - rozróżnienia dokonuje się pomiędzy jego/ jej trudnościami o charakterze językowym a trudnościami o innym podłożu. W przypadku tej pierwszej sporządza się „Indywidualny Plan Kształcenia Językowego” (Individual Language Plan). Ma on zazwyczaj formę tabeli podzielonej na 9 części: 1. dane ogólne (general information): imię i nazwisko, poziom języka angielskiego, rok/klasa, obszar(y) sprawiający(-e) trudności, wychowawca, data rozpoczęcia, data zrewidowania, nauczyciel(e) udzielający wsparcia, np. podczas innych zajęć objętych programem kształcenia, proponowane wsparcie, np. w czasie innych zajęć objętych programem kształcenia, data rozpoczęcia wsparcia, 2. cele do osiągnięcia (targets to be achieved), np. rozumienie różnych tekstów, 3. kryteria osiągnięcia (achievement criteria), np. potrafi odpowiadać na pytania dotyczące danego tekstu, 4. możliwe źródła/techniki (possible resources/techniques), np. użycie obrazków i diagramów celem wsparcia zrozumienia tekstu, użycie słownika dwujęzycznego, 5. możliwe strategie do zastosowania w klasie (possible class strategies), np. identyfikowanie słów kluczowych i głównych treści tekstu, wypełnianie testu luk, 6. pomysły dla osoby udzielającej wsparcia (ideas for suport assistant), np. pomoc w identyfikacji głównych treści tekstu, zadawanie pytań, 7. rezultat (outcome), 8. udział rodzica/opiekuna ( $p a-$ rent/carer contribution), 9. wkład ucznia (student's contribution) ${ }^{16}$.

\section{Konkluzja i wnioski}

W stosunku do dzieci i młodzieży dorastającej w podwójnych kontekstach językowokulturowych (np. polskich dzieci i młodzieży uczęszczającej do szkół w Anglii) stawia się różne oczekiwania w kwestii ich językowo-kulturowego (społecznego) rozwoju w porównaniu do jednojęzycznych dzieci wychowywanych tylko w kontekście kraju rodzimego (np. w Polsce) ${ }^{17}$. Te różne oczekiwania (i wychowawcze doświadczenia) mogą prowadzić do różnych wyników rozwojowych w odniesieniu do umiejętności regulacji emocji, interakcji społecznych i wpływu na ich dotychczasową (i dalszą) edukację (w tym językowego, społecznego, emocjonalnego) rozwoju. Wczesne lata szkolne to czas kształtowania zdolności rozumowania czy nowych poziomów wzajemnej rywalizacji (M. Jankowska 2015), a nowo przybyli uczniowie reprezentujący rozmaite mniejszości etniczne, bez wątpienia stanowią dla danej społeczności lokalnej zarówno ogromne wyzwanie, jak i czynnik niezwykle stymulujący, stwarzający - de iure i de facto - możliwości poznawania różnych języków, kultur i religii, wnoszący do niej pewne poczucie świeżości.

W celu zrozumienia koncepcji rozwoju językowego (kompetencji językowej) pamiętać trzeba, że przed teorią rozwoju myślenia i mówienia J. Piageta (1926), powszechnie uważano, że rozwój dzieci miał miejsce dopiero po tym, gdy dzieci zaczęły

\footnotetext{
${ }^{16}$ Przywołany „Indywidualny Plan Kształcenia Językowego” pochodzi z wewnątrzszkolnej dokumentacji Barnfield South Academy w Luton.

${ }^{17}$ Zob.: M. Łączek 2016b.
} 
już mówić. Dużą rolę odegrały w tym względzie również prace L. Wygotskiego (1989) i N. Chomsky'ego (1986).

Celem artykułu było zdiagnozowanie stanu angielskiej polityki oświatowej na przykładzie inspektoratu oświaty w Milton Keynes oraz umiejętności i zakresu jej stosowania względem uczniów przynależących do różnych mniejszości etnicznych, będących na różnych poziomach zaawansowania w kontekście angielskiego jako ich języka drugiego/ dodatkowego. W świetle powyższych analiz wydaje się, że konieczne jest podjęcie dalszych studiów poświęconych procesowi kształcenia mniejszości etnicznych - autor niniejszej publikacji jest $\mathrm{w}$ trakcie przeprowadzania pilotażowych badań, których wyniki udzielą odpowiedzi na dwa pytania:

1. Czy i w jakiej mierze wykorzystanie języka ojczystego/ odziedziczonego przekłada się na wyższe osiągnięcia uczniów w rozwijaniu kompetencji językowych w zakresie języka drugiego/ dodatkowego?

2. Czy i w jakiej mierze czynniki takie jak np. środowisko uczenia się i nauczania oraz społeczne (np. wykształcenie rodziców, zawód rodziców, długość pobytu, narodowość) determinują rozwój kreatywności werbalnej w zakresie języka ojczystego/ odziedziczonego oraz języka drugiego/ dodatkowego?

Rezultatem powyższych będą publikacje, odpowiednio: „Efektywność języka ojczystego w rozwijaniu kompetencji językowej w zakresie angielskiego jako języka dodatkowego na przykładzie polskich uczniów w angielskich placówkach oświatowych” oraz „Czynniki społeczne determinujące rozwój kreatywności werbalnej na przykładzie polskiej mniejszości etnicznej w Anglii” - to one przyczynią się do udzielenia ostatecznej odpowiedzi do jakiego stopnia w praktyce rozwinięta jest funkcja facylitacyjna angielskiej polityki oświatowej w zakresie kształcenia uczniów przynależących do mniejszości etnicznych.

Tytułem konkluzji można przywołać przedstawione w raporcie Study on educational support for newly arrived migrant children. Final report (2013) badania, które wykazały, że nie wszystkie nowo przybyłe dzieci migrantów mają równy dostęp do wysokiej jakości edukacji w Europie, co jest jednym z głównych wyzwań jakie stoją przed nimi i ich rodzicami po przyjeździe do kraju przyjmującego. Co więcej, nowo przybyłe dzieci migrantów i imigrantów ${ }^{18}$ nie uczestniczą $\mathrm{w}$ takim samym stopniu $\mathrm{w}$ procesie edukacji w Europie, jak ich rodzimi rówieśnicy. Powyższe czynniki z kolei powodują, że dzieci migrantów często nie radzą sobie ze szkolnymi obowiązkami tak dobrze jak ich rodzimi rówieśnicy i są narażone na wcześniejsze opuszczenie szkoły. To ostatnie, z powodu uwarunkowań prawych, nie stanowi szczególnego zagrożenia w przypadku angielskich szkół.

${ }^{18}$ E. Lipińska (2013: 7 za: P. Boski 2010: 109) używa pojęcia „(e/i)migracja”, które stanowi połączenie dwóch różnych perspektyw, tj.: emigracji i imigracji tego samego, nadrzędnego zjawiska jakim jest migracja. 


\section{Bibliografia}

Atger, A. F. (2009), Education and political participation of migrants and ethnic minorities in the EU, (w:) "Centre for European Policy Studies". (URL http://www.ceps.eu). [Pobrano 3.2.2017].

Bhatia, T.K./ W. C. Ritchie (red.), (2005), The handbook of bilingualism. Oxford.

Bialystok, E. (2001), Bilingualism in development. Language, literacy, and cognition. Cambridge.

Bloomfield, L. (1973), Language. London.

Boski, P. (2009), Kulturowe ramy zachowań spolecznych. Warszawa.

Chadderton, Ch. (2010), Educational policy and minority: ethnic young people in the UK, (w:) "Network migration in Europe". (URL http://www.migrationeducation.org). [Pobrano 14.12.2016].

Children Act (1989), (w:) "legislation.gov.uk". (URL http://www.legislation.gov.uk/ukpga/1989/41/contents). [Pobrano 1.10.2016].

Chomsky, N. (1986), Knowledge of language: its nature, origin and use. New York.

Döpke, S. (1992), One parent one language. An interactional approach. Amsterdam.

Education and Inspections Act (2006), (w:) "legislation.gov.uk". (URL http://www.legislation.gov.uk/ukpga/2006/40/contents). [Pobrano 14.11.2016].

Ethnic minorities 'more likely to go to university' than white working-class British children (2015), (w:) "Telegraph". (URL http://www.telegraph.co.uk/education/educationnews/11987142/Ethnic-minorities-more-likely-to-go-to-university-than-white-working-class-British-children.html). [Pobrano 1.3.2016].

Grosjean, F. (1982), Life with two languages. An introduction to bilingualism. Cambridge.

Grucza, F. (1981), Glottodydaktyczne implikacje bilingwizmu, (w:) „Bilingwizm a glottodydaktyka", red. F. Grucza. Warszawa, 9-35.

Grucza, S. (2013), Od lingwistyki tekstu do lingwistyki tekstu specjalistycznego. Warszawa.

Guidance on the assessment of pupils with English as an additional language who may have special educational needs (2004), (w:) "Milton Keynes Council”. (URL http://www.mkweb.co.uk/emass/). [Pobrano 22.2.2016].

Jankowska, M. (2015), On bilingualualism in (monoligual?) English classroom environment - the challenges for Polish-English bilingual children, their parents and schools, (w:) "Sustainable Multilingualism" 5, 99-131.

Kurcz, I. (2007), Psychologiczne aspekty dwujęzyczności. Gdańsk.

Lam, A. (2006), Bilingualism, (w:) R. Carter/ D. Nunan (red.), The Cambridge guide to teaching English to speakers of other languages. Cambridge, 93-99.

Laskowski, R. (2009), Język w zagrożeniu. Przyswajanie języka polskiego w warunkach polsko-szwedzkiego bilingwizmu. Kraków.

Laskowski, R. (2014), Language maintenance - language attrition. The case of Polish children in Sweden. Frankfurt am Main.

Lipińska. E./ A. Seretny (2012), Między językiem ojczystym a obcym. Nauczanie $i$ uczenie sie języka odziedziczonego na przyktadzie chicagowskiej diaspory polonijnej. Kraków. 
Lipińska, E. (2013), Polskość w Australii. O dwujęzyczności, edukacji i problemach adaptacyjnych Polonii na antypodach. Kraków.

London: Census Profile (2015), (w:) "The Migration Observatory at the University of Oxford". (URL http://www.migrationobservatory.ox.ac.uk/briefings/london-census-profile). [Pobrano 14.12.2016].

Łączek, M. (2016a). Glottodydaktyka dwujęzyczna: przegląd polskiej i angielskiej terminologii, odczyt na konferencji „Lingwistyka stosowana. 35 lat PTLS” (Uniwersytet Warszawski, Warszawa: 15-16 kwietnia 2016 roku).

Łączek, M. (2016b), Akulturacja polskich (e/i)migrantów: ,zjednoczeni w różnorodności”?, odczyt na II Międzynarodowej Konferencji „Nowy wymiar filologii języki, literatura, językoznawstwo, kultura" (Państwowa Wyższa Szkoła Zawodowa w Płocku, Płock: 18-24 kwietnia 2016 roku).

Łączek, M. (2015a), Szkolnictwo polonijne w kontekście egzolingwalnym (na przykładzie Zjednoczonego Królestwa Wielkiej Brytanii i Irlandii Pótnocnej). Od 'polskiej szkoły parafialnej' po 'Polish abroad Saturday school', odczyt na Konferencji „Nauczanie języków obcych - nowe czasy, stare problemy” (Katolicki Uniwersytet Lubelski, Lublin: 13-14 listopada 2015 roku).

Łączek, M. (2015b), Kształcenie andragogiczne a walka z bezrobociem (na przyktadzie polskiej mniejszości etnicznej zamieszkującej londyńska gminę Ealing, (w:) "Proceedings of the International Scientific Conference on MMK 2015. International Masaryk Conference for Ph.D. Students and Young Researchers" Volume VI, 1251-1262.

Łączek, M. (2014), Promoting community cohesion in English education settings on the example of Barnfield South Academy in Luton, (w:) „Zeszyty Naukowe Uczelni Warszawskiej im. Marii Skłodowskiej-Curie" Nr 4 (46)/ 2014, 17-31.

Łączek, M. (2006). Angielskie zadziwienia, (w:) „Głos Nauczycielski” 49 (13).

Migrants in Europe. A Statistical portrait of the first and second generation (2011), (w:) "Eurostat". (URL http://ec.europa.eu/eurostat/en/web/products-statisticalbooks/-/KS-31-10-539). [Pobrano 9.9.2016].

O’Driscoll, J. (1995), Britain. Oxford.

Olpińska-Szkiełko, M. (2013a), Nauczanie dwujęzyczne w świetl badań glottodydaktycznych. Warszawa.

Olpińska-Szkiełko, M. (2013b), Wychowanie dwujęzyczne w przedszkolu. Warszawa.

Ó Riagáin, P./ G. Lüdi (2003), Bilingual education: some policy issues. Strasbourg.

Peal, E. / W. E. Lambert (2007), Zwiazek dwujęzyczności z inteligencja, (w:) I. Kurcz (red.), Psychologiczne aspekty dwujęzyczności. Gdańsk, 230-268.

Piaget, J. (1926), The language and thought of the child. New York.

Special Educational Needs Code of Practice 2001, (w:) "gov.uk". (URL https://www.gov.uk/government/publications/special-educational-needs-sencode-of-practice). [Pobrano 1.7.2016].

Study on educational support for newly arrived migrant children. Final report (2013), (w:) "Sirius network". (URL www.migrationeducation.org). [Pobrano 4.9.2016]. 
The concrete future objectives of education systems 2001, COM(2001) 59 final. (URL https://www.umftgm.ro/fileadmin/consultare_publica/bibliografie/The_concrete_future_objectives_of_education_systems.pdf). [Pobrano 3.3.2016].

The national literacy strategy (1999), Department for Education and Employment. London.

Turlej, J./ J. Woźnicka (red. jęz.) (2010), Podstawa programowa dla uczniów polskich uczacych się za granica, (w:) „Polska Szkoła”. (URL http://www.polskaszkola.pl/file.php/1/Podstawa_programowa_INTERNET.pdf).

[Pobrano 1.12.2016].

Wilczyńska, W. / J. Górecka / E. Mosorka / A. Nowicka / H. Skrivánek / B. Wojciechowska (2007), Wielojęzyczność a wykorzystanie różnorodności kontekstów europejskich w nauczaniu szkolnym. Wyniki badań w dzielnicy Grunwald w Poznaniu oraz w powiecie stubickim na tle innych okręgów europejskich. Poznań.

Wygotski, L. (1989), Mowa i myślenie. Warszawa. 